\title{
Bacterial Skin and Soft Tissue Infections in Children
}

\author{
Divya Gupta
}

\begin{abstract}
Skin and soft tissue infections (SSTIs) are common in the pediatric age-group in developing countries, where the risk factors are commonplace. These SSTIs may be classified for ease of management, into uncomplicated (uSSTI) and complicated SSTIs (cSSTI). Folliculitis, furuncles, impetigo, ecthyma, and erysipelas are grouped under uSSTI, whereas abscess, carbuncle, and cellulitis come under cSSTI. Most of them are secondary to Staphylococcus aureus and group I beta-hemolytic Streptococci. Antibiotic treatment must be based on antimicrobial sensitivities and local community resistance patterns. Antibiotics like beta-lactams, first-generation cephalosporins, trimethoprim-sulfamethoxazole, and clindamycin are effective in most patients. However, methicillin-resistant Staphylococcus aureus (MRSA) is a serious concern in cases worldwide, including India. Newer molecules like dalbavancin, telavancin, tigecycline, ceftaroline, and tedizolid are emerging.

Keywords: Complicated, Pediatric, Skin and soft tissue infection, Uncomplicated.

Pediatric Infectious Disease (2021): 10.5005/jp-journals-10081-1305
\end{abstract}

\section{INTRODUCTION}

Skin and soft tissue infections (SSTIs), also known as pyodermas, are common purulent infections of the skin caused most commonly by staphylococcal or streptococcal organisms. Eighty percent of children in endemic areas are affected by pyodermas, which can range from a superficial skin infection like impetigo to a deeper skin infection like cellulitis or abscess, sometimes even necrotizing soft tissue infection. In this narrative review, the author has discussed some of the pertinent SSTIs seen in the pediatric age-group. ${ }^{1}$

\section{Classification}

There are many classifications for SSTIs. It can be classified as primary (due to direct infection of unbroken skin and subcutaneous tissue) and secondary (consequent to a previous dermatosis like eczema, pediculosis, scabies, etc.). The primary pyodermas can be classified further into follicular (folliculitis, furuncles, carbuncles, and abscess) and non-follicular pyodermas (impetigo, erysipelas, cellulitis). The most common type of pyodermas are impetigo and folliculitis.

The Infectious Diseases Society of America (IDSA) has classified the bacterial SSTIs based on practical usefulness for the clinicians: (i) skin extension: uncomplicated infections (uSSTI) with superficial involvement (impetigo, ecthyma, erysipelas, folliculitis, furunculosis), and complicated infections (cSSTI) usually with deep involvement (abscesses, cellulitis, carbuncles); (ii) rate of progression: acute (trauma-induced, bite-related, postoperative) and chronic (diabetic foot infections, stasis ulcers, pressure ulcers) wound infections; and (iii) tissue necrosis: necrotizing fasciitis (NF) (myonecrosis, gangrene) and non-necrotizing infections. ${ }^{2,3}$ An acute bacterial skin and skin structure infection (ABSSSI) is defined by the U.S. Food and Drug Administration (USFDA) as a bacterial infection of the skin with an area of redness, edema, or induration measuring at least 75 $\mathrm{cm}^{2}$. Cellulitis/erysipelas, and major cutaneous abscesses come under this category. ${ }^{4}$
Department of Dermatology, Manipal Hospital, Bengaluru, Karnataka, India

Corresponding Author: Divya Gupta, Department of Dermatology, Manipal Hospital, Bengaluru, Karnataka, India, Phone: +91 9443279833, e-mail:divya_gupta@ymail.com

How to cite this article: Gupta D. Bacterial Skin and Soft Tissue Infections in Children. Pediatr Inf Dis 2021;3(4):146-155.

Source of support: Nil

Conflict of interest: None

\section{Uncomplicated Skin and Soft Tissue INFECTIONS (USSTIS)}

\section{Folliculitis and Furunculosis}

Folliculitis is an acute purulent infection of the pilosebaceous unit, which presents as small red or white follicular papules. The most common form is superficial bacterial folliculitis which is usually caused by Staphylococcus aureus. A furuncle is an acute, larger, and more painful, and sometimes fluctuant, infection of a hair follicle characterized by a tender red perifollicular nodular swelling which later bursts open discharging pus and necrotic debris (Fig. 1). Staphylococcus aureus is the commonest pathogen present in almost all cases of furuncles. Risk factors for folliculitis as well as furuncles include over-crowding, affected individuals in close proximity, participation in contact sports, sharing items of personal use like towels, razor, etc., and poor personal hygiene. It may also complicate underlying skin diseases like eczema, scabies, tinea capitis, pediculosis, and psoriasis.

Multiple lesions (furunculosis) may appear in diabetics, malnourished, and immunosuppressed individuals. These infections usually occur on hairy skin like the scalp, face, neck, chest, and buttocks. On examination, small pustules with perifollicular inflammation can be observed. Superficial bacterial folliculitis secondary to Staphylococcus must be differentiated from gram-negative folliculitis, pityrosporum folliculitis, viral folliculitis,

(o) The Author(s). 2021 Open Access This article is distributed under the terms of the Creative Commons Attribution 4.0International License (https://creativecommons. org/licenses/by-nc/4.0/), which permits unrestricted use, distribution, and non-commercial reproduction in any medium, provided you give appropriate credit to the original author(s) and the source, provide a link to the Creative Commons license, and indicate if changes were made. The Creative Commons Public Domain Dedication waiver (http://creativecommons.org/publicdomain/zero/1.0/) applies to the data made available in this article, unless otherwise stated. 


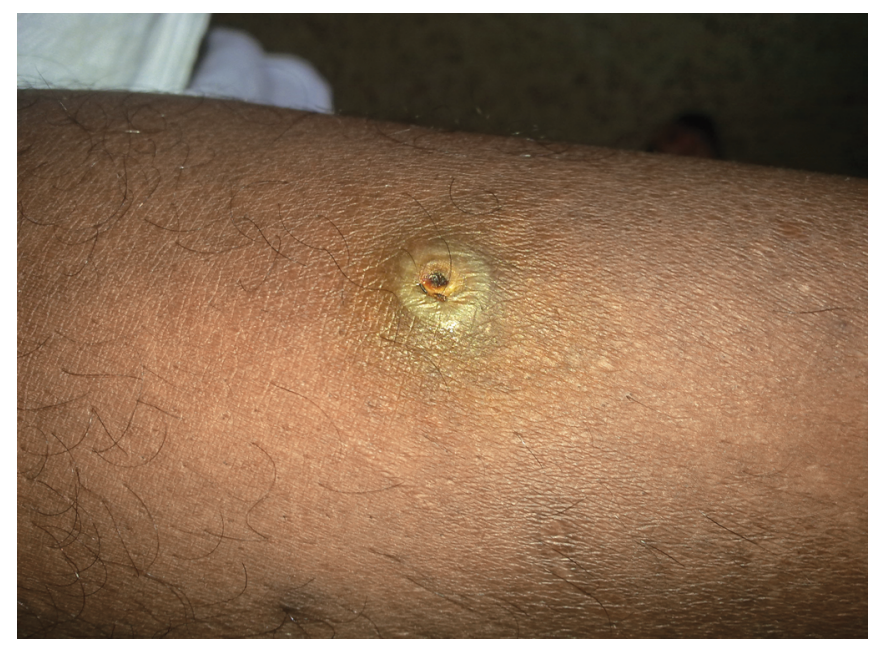

Fig. 1: Furuncle on hair bearing area of the skin

Demodex folliculitis, and acne vulgaris. Furuncles may be confused with hidradenitis suppurativa, mycobacterial infection, and acne vulgaris.

Diagnosis is generally clinical. For most simple cases of folliculitis, topical antimicrobials like $2 \%$ mupirocin or $2 \%$ fusidic acid will suffice. For small furuncles, warm compresses help in promoting drainage. For larger furuncles, incision and drainage (I\&D) will be required. For extensive disease and larger lesions, empiric antibiotic therapy with cephalexin or dicloxacillin can be started. If left untreated, there is a risk of developing into a cSSTI like cellulitis or abscess.

Recurrent furunculosis/recurrent folliculitis: Main risk factors are nasal colonization, poor hygiene, and familial spread. Inadequate choice and duration of antibiotics also contribute to recurrent infections. The most common causative organism is $S$. aureus, especially Panton-Valentine Leucocidin (PVL)+ strains. As strategies for prevention, nasal decolonization with mupirocin (twice daily for 5 days, every month for 3 months), bleach baths, chlorhexidine gluconate (chlorhexidine $4 \%$ body wash once a day for 5 days; chlorhexidine $4 \%$ shampoo on days 1, 3, and 5), tetracyclines like doxycycline or minocycline (in children $>8$ years) along with clindamycin can be employed. Rifampicin must not be used for pyoderma prevention or treatment in India to prevent the emergence of resistance. Household contacts should be decolonized as well. General measures like improved hygiene, regular bathing, and avoiding sharing items of personal use are important. ${ }^{5,6}$

\section{Impetigo}

Impetigo is a frequent skin infection in the preschool age-group. The global burden of impetigo is especially high in the poorer countries around the globe, as a result of risk factors like hot and humid climate, overcrowding, and poor hygiene. ${ }^{7}$

Group A beta-hemolytic Streptococcus (GABHS) is the most common organism but the prevalence of $S$. aureus is increasing. ${ }^{8}$ There are two clinical forms: bullous and non-bullous impetigo. The non-bullous form can be caused by both the above organisms, whereas S. aureus (often phage type 71) alone is responsible for bullous impetigo (BI). ${ }^{9}$ Non-bullous impetigo presents as a honey-colored crust, typically on the face, around nose and mouth, extremities, and scalp. Bullous impetigo is secondary to the local production of exfoliative toxin $A$ and $B$, which leads to

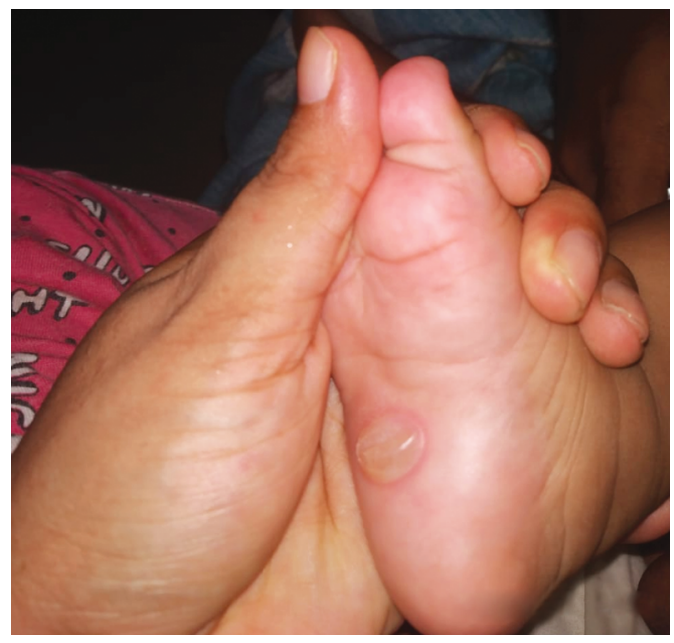

Fig. 2: Lesion of bullous impetigo

bulla formation (Fig. 2). These rupture after 2-3 days to form a thin varnish-like crust. Lesions often heal in the center to form annular plaques. $^{10}$

Uncomplicated impetigo may spontaneously resolve in 2-3 weeks without scarring. However, if left untreated, it may spread by autoinoculation. Rarely, fever, lymphadenopathy, cellulitis, osteomyelitis, septic arthritis, pneumonia, and sepsis may complicate impetigo. Non-infectious complications like scarlet fever, guttate psoriasis, and post-streptococcal glomerulonephritis, recurrent toxin-mediated perineal erythema, and staphylococcal scalded skin syndrome may also occur. ${ }^{11,12}$

Blistering (bullous) dactylitis is a type of $\mathrm{Bl}$, seen in the pediatric age-group. It typically presents as a tender, pus-filled bulla between $1 \mathrm{~cm}$ and $3 \mathrm{~cm}$ in size that ruptures to form erosions. The volar fat pad of the distal portion of a digit is the most commonly involved site. $^{13,14}$

Differential diagnosis includes scabies, tinea corporis, and eczema. The BI must be differentiated from burns, Stevens-Johnson syndrome, and other autoimmune bullous disorders. Annular plaques of resolving $\mathrm{BI}$ may be confused with tinea corporis or nummular eczema. ${ }^{15}$

\section{Treatment}

Wet compresses like Condy's compresses (dilute potassium permanganate compresses) should be used for crusted lesions. Topical antibiotics like mupirocin, fusidic acid, and retapamulin are the treatments of choice. They are applied to the affected areas twice daily for 5-7 days. ${ }^{16-19}$ Retapamulin is currently approved for the treatment of methicillin-sensitive skin infection only. ${ }^{20}$ Newer topical antibiotics like minocycline (1-4\% foam) and ozenoxacin ( $1 \%$ cream) have completed phase II double-blinded trials. These are proposed to be used in a similar dosage pattern, i.e., twice daily for 7 days. ${ }^{21,22}$ Antibiotic creams like bacitracin, erythromycin, neomycin, and rifamycin are best avoided.

In cases of extensive disease or poor response to topicals, oral antibiotics are indicated. The antibiotic choice should be guided by the culture sensitivity report and local resistance patterns. Usually, the strains of $S$. aureus responsible for causing impetigo are sensitive to methicillin and hence, penicillinase-resistant penicillins (e.g., flucloxacillin) or first-generation cephalosporins (cephalexin) will work in most cases. Indian guidelines (ICMR and National Centre for Disease Control) recommend amoxicillin/clavulanic acid as first- 


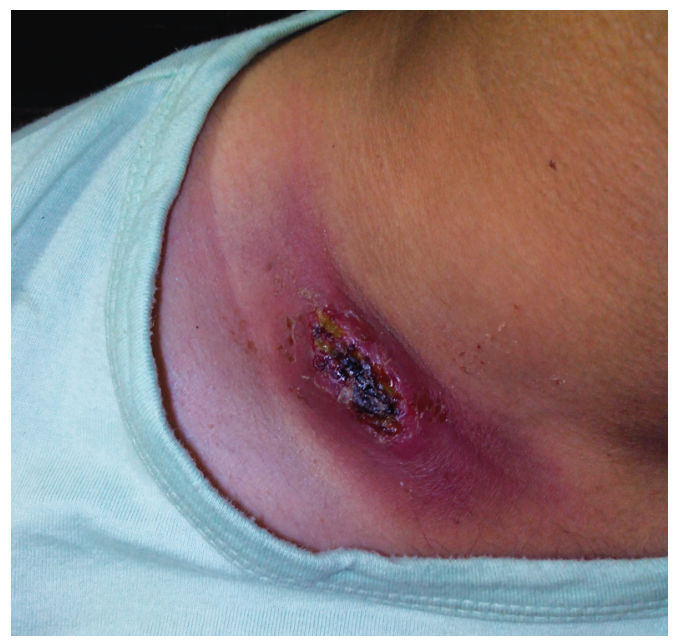

Fig. 3: Lesion of ecthyma showing an ulcer studded with a dark brown to black crust

line systemic treatment, although many experts believe that its use should be limited. Blistering (bullous) dactylitis can be treated by I\&D under appropriate antibiotic cover. ${ }^{15}$

A 1-week course is usually enough for treatment. It may be extended to 10-14 days depending on the rate of response. Oral treatment is preferred as it is well tolerated. Oxacillin can be given if a parenteral treatment is required. ${ }^{1,4,23}$

\section{Ecthyma}

Ecthyma is a deeper form of impetigo caused by group A betahemolytic streptococci. It may be associated with debilitating conditions like malnutrition and an immunosuppressed state. The lesions commonly occur on the legs. They are characterized by thickly adherent brown crusted lesions and removing the crust leads to an ulcer (as opposed to erosion of impetigo) (Fig. 3). The ulcer has a punched-out appearance when the crusts are removed and they heal slowly over a few weeks. Unlike impetigo, ecthyma is accompanied by abrupt onset of fever and malaise and resolves slowly with scarring.

This condition must be distinguished from ecthyma gangrenosum which is caused by Pseudomonas aeruginosa and usually occurs on the body flexures like axillae and anogenital area. Wound cultures can help in differentiating the two conditions.

Treatment requires beta-lactamase-resistant antibiotics for 2-3 weeks. Factors like overall poor general condition and nutrition status must be paid attention to.

\section{Erysipelas}

Erysipelas is an acute, beta-hemolytic (groups I, II, III, VII, and VI) streptococcal and uncommonly $S$. aureus infection of the skin involving the superficial dermal lymphatics and dermis. Erysipelas can happen following any inflammatory dermatosis or traumatic insult to the area. Clinical features are similar to cellulitis. But since it is a more superficial condition than cellulitis, hence the edges are more sharply demarcated in erysipelas (Fig. 4). Sharply demarcated, tender, erythematous plaques with an elevated advancing border is a typical feature. Face and legs are commonly involved areas. Sometimes upper extremities and genital region may also be involved. Constitutional symptoms such as fever, malaise, myalgia, and chills may be seen. ${ }^{24} \mathrm{~A}$

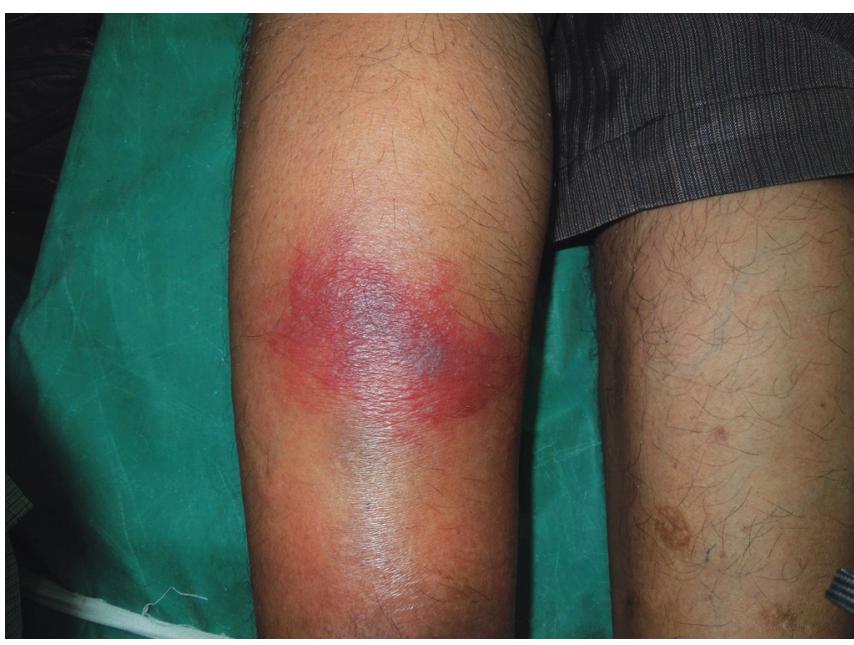

Fig. 4: A well-demarcated erythematous tender plaque of erysipelas

serious complication of erysipelas, especially for facial lesions, is cavernous sinus thrombosis. Eyes may be swollen shut with advancing erythema and edema, similar to that seen in cellulitis. Vesicles and bullae may develop on the surface followed by gangrene. Diagnosis is mainly clinical. Cultures of blood, exudate, biopsies, or swabs are low in yield and not advised. Differential diagnoses for erysipelas include acute contact dermatitis, giant urticaria, and burns.

Depending on the severity, erysipelas can be treated with oral or parenteral beta-lactams. Among the oral beta-lactams, cefprozil, cefuroxime axetil, cephalexin, cefadroxil, and beta-lactam/betalactamase inhibitor combinations such as amoxicillin-clavulanate have shown good efficacy. ICMR and NCDC guidelines recommend amoxicillin/clavulanic acid, cephalexin, or cloxacillin. Parenteral penicillinase-resistant penicillin, a first-generation cephalosporin, or beta-lactam/beta-lactamase inactivator combinations such as amoxicillin-clavulanate is recommended for serious cases. Repeated episodes may require long-term antimicrobial prophylaxis along with correction of risk factors. Recently, newer antibiotics like linezolid, daptomycin, tigecycline, telavancin, and ceftaroline have shown good results in SSTIs, including deep bacterial skin infections. ${ }^{4,25,26}$ However, advanced antibiotics like telavancin and ceftaroline are not yet widely used in India.

\section{Complicated Skin and Soft Tissue INFECTIONS \\ Carbuncle}

Bigger and deeper abscesses formed by the merging of multiple furuncles are defined as carbuncles. They are usually caused by $S$. aureus. They are deep, extremely painful and when they rupture, they form multiple draining sinuses, the latter being a typical pathognomonic feature. They can occur in individuals with immunosuppression and diabetes mellitus and are more commonly seen in older individuals instead of children. The most common site is the nape of the neck, back, breast, and buttocks. Incision and drainage is the treatment of choice along with empiric antibiotic therapy with action against $S$. aureus. The presence of many interconnecting sinuses often necessitates surgical drainage and resection to avoid recurrence. Underlying risk factors need to 
be corrected. Mupirocin prophylaxis reduces nasal colonization in Staphylococcal carriers.

\section{Abscess}

Abscesses are walled-off collections of pus, often larger, and deeper than furuncles. They may develop on hair-bearing or nonhair bearing sites and have the same predisposing conditions as furuncles (Table 1). They are quite tender and appear as a painful induration with a pustule on the tip. Initially, the swelling is tense and later gives way to become fluctuant. Large abscesses are often encircled by erythema and induration and may be associated with constitutional symptoms. ${ }^{27}$

The most common causative organism is $S$. aureus followed by Streptococcus, coagulase-negative Staphylococcus, gram-negative organisms, and anaerobes in that order. Abscesses may also be polymicrobial depending on the cause. Close to $50 \%$ of $S$. aureus isolates have shown methicillin resistance followed by clindamycin resistance (up to 13\%), and TMP-SMX resistance (up to 3\%). ${ }^{28-30}$

An abscess may also be classified as simple or complicated. A simple abscess is characterized by size up to $5 \mathrm{~cm}(\leq 3 \mathrm{~cm}$ in patients 6-11 months of age and $\leq 4 \mathrm{~cm}$ in patients $1-8$ years of age). A complicated abscess is defined as an abscess $>5 \mathrm{~cm}$ in diameter (and proportionally smaller in young children), involvement of $\geq 2$ sites, or presence of a recurrent abscess. ${ }^{1,10}$

Recurrences are common in patients with a skin abscess, especially if there is colonization with methicillin-resistant Staphylococcus aureus (MRSA) and S. aureus producing PVL toxin. Household contacts may also acquire the infection if adequate hygiene is not followed.

Differential diagnosis includes inflamed epidermoid or sebaceous cysts, hidradenitis suppurativa, foreign body granuloma, and mycobacterial skin infection.

\section{Treatment}

Incision and drainage is the treatment of choice. Small abscesses may resolve secondary to spontaneous drainage. For larger abscesses, one must probe the cavity to break up any loculations and express out all the pus and debris. ${ }^{31}$ Although ultrasoundguided needle aspiration has been advocated by some, I\&D continues to be more superior. ${ }^{32}$ Treatment with oral antibiotics for 7-10 days after I\&D can be employed. In locations with a high prevalence of MRSA, various antibiotics like TMP-SMX, clindamycin, doxycycline, minocycline (only $>8$ years group), linezolid, and fusidic acid may be useful. ${ }^{28-30,33,34}$

Table 1: Risk factors for abscesses

Atopic dermatitis
Skin injuries
Malnutrition
Diabetes
Immunodeficiency [neutrophil defect (i.e., chronic granulomatous
disease and leukocyte adhesion molecule deficiency), hyperimmu-
noglobulin E syndrome, and Wiskott-Aldrich syndrome]
Patient on steroids or other chemotherapeutic agents
Crowding and poor hygiene
Sharing of personal items that may become contaminated
Colonization by MRSA and/or colonization by S. aureus producing
PVL
Skin abscess in a household contact

Vancomycin is the antibiotic of choice for complicated abscesses. Clindamycin may be used if the local resistance rate is $<10 \%$. ${ }^{2}$ Other parenteral antibiotics like teicoplanin, daptomycin, linezolid, tigecycline, and telavancin (telavancin only in the US) may be utilized for more serious infections requiring hospitalization (Table 2). ${ }^{36}$ Newer antibiotics, especially dalbavancin and tedizolid are effective against ABSSSI and MRSA. ${ }^{37,38}$ These are, however, not yet approved in India for serious MRSA infections.

Dalbavancin, a second-generation lipoglycopeptide, was recently approved by FDA and its European counterpart, the European Medicines Agency (EMA) with a two-dose regimen of $1,000 \mathrm{mg}$ followed 1 week later by $500 \mathrm{mg}$ administered intravenously over 30 minutes (weekly dose facilitated by its prolonged half-life). The DISCOVER 1 and DISCOVER 2 studies showed that once-weekly intravenous dalbavancin was non-inferior to twice-daily vancomycin followed by oral linezolid. 4,39,40 Tedizolid, a novel oxazolidinone, administered daily in oral or intravenous forms, has shown promising results in ESTABLISH 1 and 2 studies. ${ }^{41,42}$ These are not yet approved for use in India.

\section{Cellulitis}

Group A beta-hemolytic streptococci are most commonly responsible for cellulitis. Infection of the subcutaneous tissue often follows a furuncle, a wound, or infected skin lesions. It is characterized by diffuse erythema, edema, swelling, and tenderness. The edges are ill-defined (Fig. 5). Constitutional Table 2: Indication for hospitalization ${ }^{35}$

\section{Muscle or fascial involvement is suspected}

Rapid progression

Signs of toxemia

Doubtful diagnosis or prognosis

Exploratory surgery is contemplated

Poor compliance with outpatient treatment

Table 3: Risk factors for cellulitis

Skin lesions, e.g., burns, wounds

Surgical incisions

Insect bites

Traumatic injuries, and other conditions with loss of skin integrity

Anal streptococcal colonization in children

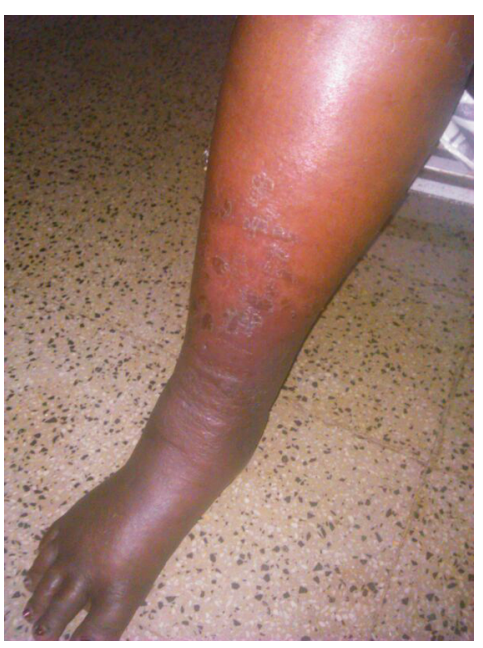

Fig. 5: Cellulitis of right leg 
symptoms can be mild or marked. Associated lymphangitis and lymphadenopathy are quite frequent. Rarely, blisters, purpuric or ecchymotic areas, pustules, and abscessed areas may be present. Cellulitis recurrence can also occur ${ }^{43}$ (Table 3 ).

Cellulitis can also be of two types: complicated and uncomplicated. Cellulitis is said to be complicated if it occurs in presence of an abscess requiring surgical drainage, necrosis, gangrene, lymphadenitis, sepsis, underlying soft-tissue malformation, bite or penetrating injury, foreign body, fracture, lymphedema, medical comorbidities, and immunosuppression. Imaging is a useful tool to detect complications like gas or abscess formation and must be performed if suspected. ${ }^{44}$

Antibiotics effective against Streptococci must be started immediately. If the cellulitis is early and mild and there are no significant comorbidities, then oral beta-lactams or first-generation cephalosporin (i.e., cephalexin) for 1-2 weeks (or until complete resolution) is sufficient. Macrolides and lincosamides can also be used, but resistance to them is increasing. For uncomplicated mild cellulitis suspected to be secondary to MRSA, there are various options. One may prescribe either oral TMP-SMX or clindamycin. Clindamycin must be used only if the local clindamycin resistance rate is $<10 \%$. The antibiotics may be continued for $1-2$ weeks or until complete resolution. ${ }^{45,46}$

For uncomplicated cellulitis that is moderate/severe in nature, intravenous penicillin or first-generation cephalosporin can be started empirically, for at least 48 hours before changing over to oral. Uncomplicated moderate to severe cases with a high incidence of community MRSA should be treated by intravenous vancomycin, or TMP-SMX or clindamycin. Oral amoxicillin/clavulanic acid or cephalosporin (e.g., cephalexin) could be instituted when systemic symptoms reduce. Antibiotics should ideally be given for 2 weeks or until complete resolution. ${ }^{1}$

The intravenous route is the first choice for more complicated and severe infections. Treatment must be started with vancomycin or teicoplanin or clindamycin and coverage against gram-negative anaerobes (i.e., piperacillin/tazobactam or imipenem-meropenem) must be added in cases of surgical site infection, bite or penetrating injury, foreign body, fracture, medical comorbidities, and immunosuppression. Scale-down to oral treatment can be done 3-5 days after intravenous treatment and when systemic symptoms have resolved. ${ }^{1,43,47}$

If complicated, severe cellulitis secondary to MRSA, glycopeptides, and newer antibiotics like linezolid, daptomycin, telavancin (latter only in the USA), and tigecycline can be considered. ${ }^{25}$ Dalbavancin and tedizolid, in limited use outside India currently, also can be administered on a case-by-case basis. ${ }^{4,26,48}$

In cases of risk factors for $P$. aeruginosa (i.e., surgical drainage, bite or penetrating injury, foreign body, fracture, medical comorbidities, immunosuppression), a 14-21-day course of oral ciprofloxacin should be considered.

\section{Necrotizing Fasciitis}

Necrotizing fasciitis (NF) is a subset of the aggressive SSTIs that cause necrosis of the muscle fascia and subcutaneous tissues. It can affect any body part, including, but not limited to, scrotum and perineum, the abdominal wall, or the extremities. The infection has a rapid rate of progression with a high mortality rate of close to $30 \% .{ }^{4,49}$

Necrotizing fasciitis is classified into three types, depending on microbiological findings. Type I is characterized by polymicrobial infection, caused by both aerobic and anaerobic bacteria which are often bowel flora derived. This subtype is more common in older individuals. Type 2 NF is usually monomicrobial and is secondary to gram-positive organisms like S. aureus (including MRSA) and group A Streptococci (GAS) alone or in synergism. Toxin production leading to toxic shock syndrome has been suggested as one of the mechanisms. This type is not associated with any specific age-group. Some experts have proposed type III infection that is caused by uncommon and often marine-related organisms like Peptostreptococcus spp., Enterobacteriaceae, Proteus spp., Pseudomonas spp., Klebsiella pneumoniae, Vibrio vulnificus, and Aeromonas hydrophila. These organisms are more virulent and produce more severe clinical manifestations. ${ }^{4}$

The overlying skin, which appears unaffected initially, gradually turns erythematous, reddish-purple to bluish-grey hue. It rapidly becomes indurated, shiny, and warm. Crepitus may be present. At this stage, there is extreme tenderness which is out of proportion to the symptoms. Skin necrosis and ulceration begin in the next 3-5 days. Bullae, ecchymosis, dysesthesia, and paresthesia may be present which ultimately result in cutaneous gangrene. Pain comes down after thrombosis of small vessels and destruction of the superficial nerves in the skin. If left untreated, it will rapidly progress to fever, tachycardia, and sepsis. The infection can spread rapidly within hours hence suspicion should be high for NF in the presence of intense pain. Patients may have underlying comorbidities like a history of skin or mucosal breach secondary to surgery, immunosuppression, malignancy, vascular disease, or diabetes. $^{50}$

Laboratory risk indicator for necrotizing infection (LRINEC) score is used to stratify the severity of NF. It takes into account the total white blood cell count, hemoglobin, sodium, glucose, creatinine, and C-reactive protein values and scores of 6 or more are indicative of NF. ${ }^{51}$

Diagnosis is mainly clinical. Gram's stain and culture and sensitivity of the aspirated material help confirm the diagnosis. Imaging technologies like bedside color Doppler ultrasound and computed tomography (CT) scan (imaging investigation of choice) can also aid in early diagnosis.

Surgery is the treatment of choice and must not be delayed for want of any lab or imaging tests. A recent meta-analysis found that time is of the essence while treating necrotizing soft tissue infections. Mortality was significantly lower for patients who underwent surgery within 6 hours (19\% mortality rate) after presentation compared to when surgery was delayed $>6$ hours (32\% mortality rate). Source control is extremely important and this may include surgical debridement and removal of invasive devices. Amputation of the extremity may need to be performed if the infection is severe and continuing to spread. ${ }^{52}$ Vacuum-assisted closure aids in wound healing. ${ }^{53}$

Antibiotics covering MRSA like vancomycin or linezolid in combination with piperacillin-tazobactam, a carbapenem, or ceftriaxone-metronidazole should be started at the earliest. Clindamycin should also be included in empiric therapy due to its effect on toxins released by certain organisms, including $S$. aureus and GAS. Once the investigation results are available, the clinician can switch to specific therapy keeping in mind local antibiotic susceptibility patterns. For known or suspected Vibrio spp. Necrotizing fasciitis, doxycycline plus a third-generation cephalosporin is recommended. For known or suspected Aeromonas infections, doxycycline is recommended in combination 
with ciprofloxacin. I.V. fluids and vasopressors must be kept handy for hemodynamically unstable patients. ${ }^{49,54}$

A recent review found insufficient evidence for or against the use of adjunctive hyperbaric oxygen therapy (HBOT). For centers with HBOT readily available, its use can be considered, but should not be a substitute for surgical or antimicrobial therapy. Intravenous immunoglobulin (IVIG) has been suggested as a treatment for superantigen-mediated toxic shock syndrome due to streptococcal or staphylococcal NF. It is believed that it binds and inactivates circulating superantigens, thereby blunting the superantigen- mediated cytokine cascade. However, data supporting this remain anecdotal. ${ }^{53,54}$

Commonly used antibiotics with their pediatric dosages are depicted in Table 4 and 5.

\section{Methicillin-resistant Staphylococcus aureus}

Methicillin-resistant Staphylococcus aureus, both community and hospital-acquired, is increasingly becoming a common isolate from various SSTIs, thus posing a serious worldwide health concern.

Table 4: Table summarizing NCDC (2016), AlIMS, and ICMR (2019) treatment guidelines for antimicrobial use in skin and soft tissue infections

\begin{tabular}{|c|c|c|c|c|}
\hline Condition & Organism & $\begin{array}{l}\text { Empiric antibiot- } \\
\text { ics (presumptive } \\
\text { antibiotics) }\end{array}$ & $\begin{array}{l}\text { Alternative anti- } \\
\text { biotics }\end{array}$ & Comments \\
\hline $\begin{array}{l}\text { Impetigo with numerous lesions, } \\
\text { ecthyma, bullous impetigo, to con- } \\
\text { trol transmission during outbreaks }\end{array}$ & Staphylococcus aureus & $\begin{array}{l}\text { Amoxicillin- } \\
\text { clavulanate }\end{array}$ & $\begin{array}{l}\text { Cephalexin or } \\
\text { cefuroxime }\end{array}$ & $\begin{array}{l}\text { Duration 5-7 days; if suspicion of } \\
\text { MRSA: preferred: linezolid; alterna- } \\
\text { tive: cotrimoxazole }\end{array}$ \\
\hline Non-bullous impetigo (few lesions) & Group A Streptococcus (GAS) & $\begin{array}{l}\text { Topical mupi- } \\
\text { rocin BD }\end{array}$ & $\begin{array}{l}\text { Topical fusidic } \\
\text { acid BD }\end{array}$ & $\begin{array}{l}\text { Blood culture is not essential-du- } \\
\text { ration: } 5-7 \text { days }\end{array}$ \\
\hline Furunculosis & Staphylococcus aureus & $\begin{array}{l}\text { Amoxicillin- } \\
\text { clavulanate or } \\
\text { ceftriaxone IV for } \\
\text { severe infection }\end{array}$ & Clindamycin & $\begin{array}{l}\text { Duration-5-7 days; get pus cul- } \\
\text { tures before starting antibiotics; } \\
\text { parenteral route to be considered } \\
\text { for severe infection only }\end{array}$ \\
\hline \multirow[t]{2}{*}{ Abscess } & S. pyogenes, oral anaerobes & $\begin{array}{l}\text { Amoxicillin- } \\
\text { clavulanate } \\
\text { OR ampicillin- } \\
\text { sulbactam (for } \\
\text { severe infection) }\end{array}$ & Clindamycin & Duration 5-7 days \\
\hline & $\begin{array}{l}\text { S. aureus, facultative gram- } \\
\text { negative anaerobes }\end{array}$ & $\begin{array}{l}\text { Linezolid OR, } \\
\text { vancomycin, } \\
\text { PLUS, ciprofloxa- } \\
\text { cin }\end{array}$ & & Duration generally, 14 days \\
\hline $\begin{array}{l}\text { Erysipelas with no signs of systemic } \\
\text { toxicity }\end{array}$ & Group A Streptococcus (GAS) & $\begin{array}{l}\text { Amoxicillin- } \\
\text { clavulanate }\end{array}$ & $\begin{array}{l}\text { Cephalexin or } \\
\text { cefuroxime }\end{array}$ & Duration 5-7 days \\
\hline $\begin{array}{l}\text { Erysipelas with signs of systemic } \\
\text { toxicity/Rapid progression of symp- } \\
\text { toms despite } 48 \text { hours of oral }\end{array}$ & Group A Streptococcus (GAS) & $\begin{array}{l}\text { Injection ceftri- } \\
\text { axone }\end{array}$ & Clindamycin & Duration 5-14 days \\
\hline $\begin{array}{l}\text { Cellulitis without signs of systemic } \\
\text { toxicity }\end{array}$ & $\begin{array}{l}\text { Streptococcus pyogenes (com- } \\
\text { mon), Staphylococcus aureus }\end{array}$ & $\begin{array}{l}\text { Tab amoxicillin- } \\
\text { clavulanate for } \\
5-7 \text { days }\end{array}$ & $\begin{array}{l}\text { Cefazolin; Or } \\
\text { cephalexin; Or } \\
\text { cloxacillin; OR } \\
\text { clindamycin }\end{array}$ & $\begin{array}{l}\text { If MRSA suspected-cotrimoxazole } \\
\text { or linezolid }\end{array}$ \\
\hline $\begin{array}{l}\text { Cellulitis with signs of systemic tox- } \\
\text { icity/rapid progression of symptoms } \\
\text { despite } 48 \text { hours of oral/proximity } \\
\text { of the lesion to an indwelling medi- } \\
\text { cal device }\end{array}$ & $\begin{array}{l}\text { Streptococcus pyogenes (com- } \\
\text { mon), Staphylococcus aureus }\end{array}$ & $\begin{array}{l}\text { Injection vanco- } \\
\text { mycin or injec- } \\
\text { tion ceftriaxone } \\
\text { or injection } \\
\text { amoxicillin- } \\
\text { clavulanate }\end{array}$ & $\begin{array}{l}\text { Teicoplanin or } \\
\text { clindamycin }\end{array}$ & $\begin{array}{l}\text { Other alternatives: linezolid or } \\
\text { daptomycin for 5-14 days }\end{array}$ \\
\hline \multirow[t]{2}{*}{ Necrotizing fasciitis } & $\begin{array}{l}\text { Streptococcus pyogenes, } \mathrm{S} \text {. } \\
\text { aureus, anaerobes, Entero- } \\
\text { bacteriaceae (polymicrobial) }\end{array}$ & $\begin{array}{l}\text { Piperacillin- } \\
\text { tazobactam or } \\
\text { cefoperazone- } \\
\text { sulbactam AND } \\
\text { clindamycin Plus, } \\
\text { MRSA coverage } \\
\text { (vancomycin/ } \\
\text { teicoplanin/lin- } \\
\text { ezolid) }\end{array}$ & $\begin{array}{l}\text { Imipenem or } \\
\text { meropenem } \\
\text { AND clindamy- } \\
\text { cin plus, MRSA } \\
\text { coverage linezol- } \\
\text { id/daptomycin }\end{array}$ & $\begin{array}{l}\text { Duration depends on the pro- } \\
\text { gress; early surgical intervention } \\
\text { crucial }\end{array}$ \\
\hline & $\begin{array}{l}\text { Aeromonas } / \text {. vulnificus } \\
\text { (suspect when the history } \\
\text { of exposure to freshwater or } \\
\text { saltwater, respectively) }\end{array}$ & $\begin{array}{l}\text { Ciprofloxacin }+ \\
\text { doxycycline }\end{array}$ & & $\begin{array}{l}\text { Generally, } 14 \text { days if adequate } \\
\text { source control achieved }\end{array}$ \\
\hline
\end{tabular}


Table 5: Dosage guide for commonly used antimicrobial agents in skin and soft tissue infections

\begin{tabular}{|c|c|c|}
\hline Antibiotic & Pediatric dose & Side effects \\
\hline $\begin{array}{l}\text { Amoxycillin-clavula- } \\
\text { nate (Co-amoxiclav) }\end{array}$ & $\begin{array}{l}\text { Based on amoxycillin dose: } 125-250 \mathrm{mg} \text { Q } 8 \text { hours; chil- } \\
\text { dren weighing < } 40 \mathrm{~kg} \text { : } 20-40 \mathrm{mg} / \mathrm{kg} / \mathrm{day} \text { (amoxicillin) in } \\
2-3 \text { divided doses; infants }<3 \text { months: up to } 30 \mathrm{mg} / \mathrm{kg} / \\
\text { day in divided doses every } 12 \text { hours }\end{array}$ & Rash, diarrhea, abdominal, AST ALT elevation \\
\hline Ampicillin-sulbactam & $\begin{array}{l}\geq 1 \text { year: Usual dose: } 300 \mathrm{mg} \text { (ampicillin } 200 \mathrm{mg} \text { and } \\
\text { sulbactam } 100 \mathrm{mg} \text { )/ } \mathrm{kg} / \mathrm{day} \text {, to be given in } 4 \text { equally } \\
\text { divided doses; up to } 200-300 \mathrm{mg} / \mathrm{kg} / \text { day of ampicillin, } \\
\text { given in } 4 \text { equally divided doses may be used in infants } \\
\geq 1 \text { month of age }\end{array}$ & $\begin{array}{l}\text { Thrombophlebitis, fatigue, headache, Gl disturbance, dysu- } \\
\text { ria, urinary retention }\end{array}$ \\
\hline Azithromycin & $10 \mathrm{mg} / \mathrm{kg} /$ day once daily & $\begin{array}{l}\text { Leukopenia, transient elevation of liver enzymes, renal } \\
\text { toxicity }\end{array}$ \\
\hline Cefadroxil & $30 \mathrm{mg} / \mathrm{kg} /$ day in 2 doses & Rash, eosinophilia \\
\hline Cephalexin & $25-100 \mathrm{mg} / \mathrm{kg} /$ day in 3-4 divided doses; max $4 \mathrm{~g}$ daily & $\begin{array}{l}\text { Transient neutropenia, AST and ALT elevation, arthralgia, } \\
\text { rash, eosinophilia }\end{array}$ \\
\hline Cefazolin & $\begin{array}{l}>1 \text { month: } 25-50 \mathrm{mg} / \mathrm{kg} / \text { day in } 3-4 \text { divided doses; max } \\
100 \mathrm{mg} / \mathrm{kg} \text { daily for severe infections }\end{array}$ & $\begin{array}{l}\text { Nausea, vomiting, diarrhea, rash, leukopenia, elevated } \\
\text { transaminases }\end{array}$ \\
\hline $\begin{array}{l}\text { Cefoperazone-sul- } \\
\text { bactam }\end{array}$ & $\begin{array}{l}\text { Ratio of cefoperazone:sulbactam is } 1: 1 \text {. Doses are } \\
\text { expressed in terms of cefoperazone. Recommended } \\
\text { dose: } 20-40 \mathrm{mg} / \mathrm{kg} / \text { day given in divided doses every } \\
\text { 6-12 hours. For serious infections: up to } 160 \mathrm{mg} / \mathrm{kg} / \text { day } \\
\text { given in } 2-4 \text { divided doses. Max dose of sulbactam } 80 \\
\mathrm{mg} / \mathrm{kg} / \text { day }\end{array}$ & Rash, eosinophilia, GI disturbances \\
\hline Cefuroxime & $\begin{array}{l}30-60 \mathrm{mg} / \mathrm{kg} / \text { day, may increase to } 100 \mathrm{mg} / \mathrm{kg} / \text { day if } \\
\text { necessary, in 3-4 divided doses }\end{array}$ & $\begin{array}{l}\text { Nausea, vomiting, diarrhea, anaphylaxis, pseudomembra- } \\
\text { nous colitis, Steven-Johnson syndrome }\end{array}$ \\
\hline Ceftriaxone & $\begin{array}{l}<50 \mathrm{~kg}: 25-50 \mathrm{mg} / \mathrm{kg} \text { once daily increased to } 80 \mathrm{mg} / \mathrm{kg} \\
\text { in severe infections; doses }>50 \mathrm{mg} / \mathrm{kg} \text { should be given } \\
\text { as IV infusion; IV infusion in neonates should be given } \\
\text { over } 60 \text { minutes; Max dose (neonates): } 50 \mathrm{mg} / \mathrm{kg} / \text { day }\end{array}$ & $\begin{array}{l}\text { Anaphylaxis, diarrhea, local reactions, blood dyscrasias, } \\
\text { rash, elevated transaminases }\end{array}$ \\
\hline Ciprofloxacin & $20-30 \mathrm{mg} / \mathrm{kg} /$ day in 2 divided doses & $\begin{array}{l}\text { Nausea, vomiting, abdominal discomfort, arthralgia, photo- } \\
\text { sensitivity transient elevation of liver enzymes }\end{array}$ \\
\hline Clindamycin & $\begin{array}{l}15-40 \mathrm{mg} / \mathrm{kg} / \text { day in } 3-4 \text { divided doses; children weigh- } \\
\text { ing }<10 \mathrm{~kg} \text { should receive at least } 37.5 \mathrm{mg} \mathrm{Q} 8 \text { hours }\end{array}$ & $\begin{array}{l}\text { Diarrhea, nausea, pseudomembranous colitis, skin rash, } \\
\text { erythema multiforme, raised ALT AST, thrombocytopenia, } \\
\text { leukopenia }\end{array}$ \\
\hline Cloxacillin & $50-100 \mathrm{mg} / \mathrm{kg} /$ day in 3-4 divided doses & $\begin{array}{l}\text { Dose-related neutropenia, elevated AST, ALT, cholecystitis } \\
\text { interstitial nephritis }\end{array}$ \\
\hline Cotrimoxazole & $\begin{array}{l}-10 \mathrm{mg} / \mathrm{kg} / \text { day in } 2 \text { divided doses; } 6 \text { weeks to } 5 \\
\text { months: } 120 \mathrm{mg} \text { BD; } 6 \text { months to } 5 \text { years: } 240 \mathrm{mg} \mathrm{BD;} \\
6-12 \text { years: } 480 \mathrm{mg} \mathrm{BD}\end{array}$ & $\begin{array}{l}\text { Megaloblastic anemia, disturbance, rash, erythema multi- } \\
\text { forme major/minor }\end{array}$ \\
\hline Daptomycin & $\begin{array}{l}\text { 12-17 years: } 5 \text { mg/kg IV Q } 24 \text { hours; } 7-11 \text { years: } 7 \text { mg/ } \\
\text { kg IV Q } 24 \text { hours; } 2-6 \text { years: } 9 \text { mg/kg IV Q } 24 \text { hours; } 1 \text { to } \\
<2 \text { years: } 10 \text { mg/kg IV Q } 24 \text { hours; <1 year: safety and } \\
\text { efficacy not established }\end{array}$ & $\begin{array}{l}\text { Insomnia, chest pain, elevated creatine phosphokinase, } \\
\text { edema }\end{array}$ \\
\hline Doxycycline & $\begin{array}{l}>8 \text { years and }<45 \mathrm{~kg} \text { : initially } 4 \mathrm{mg} / \mathrm{kg} \text { in } 2 \text { divided } \\
\text { doses followed by } 2 \mathrm{mg} / \mathrm{kg} \text { daily }\end{array}$ & $\begin{array}{l}\text { Permanent staining of teeth, rash, Gl disturbance, hemolytic } \\
\text { anemia, thrombocytopenia }\end{array}$ \\
\hline Linezolid & 10 mg/kg/dose 6-8 hourly (oral, IV) & $\begin{array}{l}\text { Peripheral and optic neuropathy, thrombocytopenia, hy- } \\
\text { pertension, myelosuppression, colitis }\end{array}$ \\
\hline Imipenem & $\begin{array}{l}>40 \mathrm{~kg}: 1-2 \mathrm{~g} \text { IV in } 3-4 \text { divided doses (max dose } 4 \mathrm{~g} / \text { day } \\
\text { or } 50 \mathrm{mg} / \mathrm{kg} \text { ); }>3 \text { months and }<40 \mathrm{~kg}: 15-25 \mathrm{mg} / \mathrm{kg} \mathrm{Q} 6 \\
\text { hours by IV infusion (max dose } 2 \mathrm{~g} / \mathrm{day} \text { ); neonates and } \\
\text { infants }<3 \text { months: } 25 \mathrm{mg} / \mathrm{kg} \mathrm{Q} 6-12 \text { hours }\end{array}$ & $\begin{array}{l}\text { Skin rash, eosinophilia, fever, tongue discoloration, altered } \\
\text { taste }\end{array}$ \\
\hline Meropenem & $\begin{array}{l}>50 \mathrm{~kg}: 500 \mathrm{mg} \mathrm{Q} 8 \text { hours; } \geq 3 \text { months and }<50 \mathrm{~kg}: 10 \\
\mathrm{mg} / \mathrm{kg} \text { ( } \mathrm{max} 500 \mathrm{mg} \text { every } 8 \text { hours) }\end{array}$ & $\begin{array}{l}\text { Hypotension, transient elevation of liver enzymes, renal } \\
\text { modification in renal failure }\end{array}$ \\
\hline Metronidazole & $7.5 \mathrm{mg} / \mathrm{kg} /$ day dose 3 times/day & $\begin{array}{l}\text { Nausea, metallic taste, disulfiram-like reaction with alcohol, } \\
\text { peripheral neuropathy }\end{array}$ \\
\hline $\begin{array}{l}\text { Piperacillin-tazobac- } \\
\text { tam }\end{array}$ & $\begin{array}{l}\text { 2-8 months: } 80 \mathrm{mg} \text { of piperacillin/kg Q } 8 \text { hours; } \geq 9 \\
\text { months and } \leq 40 \mathrm{~kg}: 100 \mathrm{mg} \text { of piperacillin } / \mathrm{kg} \text { Q } 8 \text { hours }\end{array}$ & $\begin{array}{l}\text { Leukopenia, transient elevation of liver enzymes, renal } \\
\text { toxicity }\end{array}$ \\
\hline
\end{tabular}


Contd...

Teicoplanin

Tigecycline

Vancomycin
Loading dose: $10 \mathrm{mg} / \mathrm{kg} /$ day/dose every 12 hours for 3 doses followed by $6-10 \mathrm{mg} / \mathrm{kg} /$ day depending on the severity of infection; neonates: loading dose $16 \mathrm{mg} / \mathrm{kg}$ on the first day followed by a maintenance dose of 8 $\mathrm{mg} / \mathrm{kg} /$ day

Initial: $100 \mathrm{mg}$ IV infusion, then $50 \mathrm{mg}$ IV infusion Q 12 hours; safety and efficacy not established in $<18$ years

Various dosing regimens available; 1 month to 18 years old: $40-60 \mathrm{mg} / \mathrm{kg} /$ day in 3-4 divided doses ( $\max 2 \mathrm{~g}$ daily). Neonates: $<29$ weeks postmenstrual age: $15 \mathrm{mg} /$ kg Q 24 hours; 29-35 weeks postmenstrual age: $15 \mathrm{mg} /$ kg Q 12 hours; > 35 weeks postmenstrual age: $15 \mathrm{mg} /$ kg Q 8 hours
Hypersensitivity reactions, rash, less nephrotoxic as compared to vancomycin

Nausea, vomiting, allergic reactions, photosensitivity, pseudotumor cerebri, pancreatitis. No dose adjustment to renal failure

Redman syndrome, ototoxicity, nephrotoxicity
Table 6: Risk factors for methicillin-resistant Staphylococcus aureus colonization in children

\begin{tabular}{l}
\hline Age $<6$ months and $8-13$ years \\
Male sex \\
No. of siblings \\
Children on camping trips \\
Children in daycare \\
MRSA-positive parent \\
Household members working in a healthcare facility \\
Previous hospitalization of a family member \\
Regular visit to a healthcare facility and previous hospitalization \\
History of an indwelling catheter or other medical devices \\
Chronic skin diseases
\end{tabular}

Studies across the country have shown varying results regarding MRSA prevalence. Out of 709 hospitalized patients with nosocomial S. aureus SSTIs at three tertiary care hospitals in New Delhi, MRSA was associated with 41,31 , and $7.5 \%$ of infections at each of the three hospitals. ${ }^{35,55}$ In another survey carried out in a tertiary care center in Tamil Nadu, $46 \%$ out of $106 \mathrm{~S}$. aureus isolates causing SSTIs were found to be methicillin-resistant. ${ }^{56}$ In a study conducted in Mumbai, 619 isolates were recovered in various SSTIs. No MRSA was found in CA SSTIs, whereas $45 \%$ of HA S. aureus strains were methicillin-resistant. ${ }^{57}$ Hence, MRSA prevalence varies not only from region to region but also from institution to institution within a region. It is important to know MRSA prevalence in one's hospital or local community for an effective antibiotic prescription. Strategies for managing this issue necessitate knowledge of the local prevalence of MRSA, and patient risk factors (Table 6).

The following recommendations (2016) from National Centre for Disease Control, India must be kept in mind while treating MRSA infections:

- Though MRSA strains may be reported as susceptible to fluoroquinolones, aminoglycosides, chloramphenicol, and doxycycline in vitro, these drugs are NOT to be used alone or as initial treatment for serious MRSA infections.

- Rifampicin use should be avoided in diseases other than mycobacterial diseases. Rifampicin should not be prescribed in our country for any treatment other than for Mycobacteria and chemoprophylaxis of meningococcal meningitis in clinically indicated populations. Rifampicin should not be prescribed alone as an anti-bacterial.
- The drug of choice for the treatment of infections due to MRSA is the glycopeptides, i.e., vancomycin and teicoplanin.

- Linezolid can be used to treat SSTIs caused by MRSA. Linezolid should only be prescribed after consulting an infectious disease (ID) specialist or clinical microbiologist and a mandatory order form completed.

- Mupirocin local application (intranasally bid $\times 5$ days) should be used for eradicating nasal carriage.

- Daptomycin: Daptomycin is a newer intravenous antibiotic with action against $S$. aureus. It may be used for complicated skin infections caused by MRSA.

\section{Diagnosis of Skin and Soft Tissue INFECTIONS}

- Gram's stained smear: This is a rapid and simple bedside test that can give initial information about the causative organism.

- The culture and sensitivity of purulent material help in selecting the right antibiotic. Care should be taken to avoid superficial swabs, as they would yield only commensal microorganisms.

- Blood cultures are not useful for uSSTIs because of low positive yield. Across various studies, the rates of true-positive blood culture have ranged from 0 to $<3 \%$. Isolated organisms usually include MRSA, MSSA, S. pyogenes, and Streptococcus pneumoniae and thus, doing a blood culture usually does not lead to any change in antibiotics. The current guidelines from the IDSA do not recommend blood cultures for uSSTIs. However, blood cultures may be for cSSTIs in immunosuppressed individuals, animal bites, surgical or traumatic wounds, infected ulcers, burns, and in neonates given their relative immunocompromised state compared with older children. ${ }^{58}$

- Molecular diagnosis: Traditional bacterial culture and sensitivity methods may be associated with a delay in results. Molecular techniques, including PCR-based technologies, are often employed to arrive at an accurate diagnosis quickly. These are especially very useful for SSTIs caused by S. aureus as they can rapidly detect $P V L$ encoding genes from the pus samples.

- Imaging: X-ray helps in detecting the presence of gas in the soft tissues, suggesting a necrotizing infection, and also reveals any underlying osteomyelitis. Computed tomography scans and magnetic resonance imaging (MRI) are being used increasingly, with the latter considered the investigation of choice for SSTI because of its great soft-tissue contrast. However, 
ultrasonography (US) may be more advantageous in some settings, given that it is economical, easy to perform, does not have side effects, and can be performed even in individuals with contraindications to MRI. It has a good degree of sensitivity in differentiating cellulitis from the abscess. ${ }^{4}$

\section{Conclusion}

Bacterial SSTIs are the commonest infections in the Indian pediatric population and other developing countries. They not only contribute to significant morbidity and mortality but they also have important consequences as far as the economic impact is considered. Because of the ubiquitous occurrence and trivial nature of the lesions, parents often neglect to seek healthcare facilities for pyodermas which can lead to complications later on. Hence, awareness regarding the importance of medical care for common skin infections should be created among the general population and primary healthcare workers. Information and education about risk factors and strategies for their mitigation must be a part of various health programs.

\section{References}

1. Galli L, Venturini E, Bassi A, et al. Common community-acquired bacterial skin and soft-tissue infections in children: an intersociety consensus on impetigo, abscess, and cellulitis treatment. Clin Ther 2019;41(3):532-551.e17. DOI: 10.1016/j.clinthera.2019.01.010.

2. Stevens DL, Bisno AL, Chambers HF, et al. Practice guidelines for the diagnosis and management of skin and soft tissue infections: 2014 update by the Infectious Diseases Society of America. Clin Infect Dis Off Publ Infect Dis Soc Am 2014;59(2):147-159. DOI: 10.1093/cid/ ciu444.

3. Research C for DE and. Acute Bacterial Skin and Skin Structure Infections: Developing Drugs for Treatment [Internet]. U.S. Food and Drug Administration. FDA; 2020 [cited 2020 Oct 24]. Available from: https://www.fda.gov/regulatory-information/search-fda-guidancedocuments/acute-bacterial-skin-and-skin-structure-infectionsdeveloping-drugs-treatment.

4. Esposito S, Bassetti M, Concia E, et al. Diagnosis and management of skin and soft-tissue infections (SSTI). A literature review and consensus statement: an update. J Chemother Florence Italy 2017;29(4):197-214. DOI: 10.1080/1120009X.2017.1311398.

5. Fritz SA, Hogan PG, Hayek G, et al. Household versus individual approaches to eradication of community-associated Staphylococcus aureus in children: a randomized trial. Clin Infect Dis Off Publ Infect Dis Soc Am 2012;54(6):743-751. DOI: 10.1093/cid/cir919.

6. Davido B, Dinh A, Salomon J, et al. Recurrent furunculosis: efficacy of the CMC regimen-skin disinfection (chlorhexidine), local nasal antibiotic (mupirocin), and systemic antibiotic (clindamycin). Scand J Infect Dis 2013;45(11):837-841. DOI: 10.3109/00365548.2013.810815.

7. Bowen AC, Mahé A, Hay RJ, et al. The global epidemiology of impetigo: a systematic review of the population prevalence of impetigo and pyoderma. PLoS ONE 2015;10(8):e0136789. DOI: 10.1371/ journal.pone.0136789.

8. Bernard P, Jarlier V, Santerre-Henriksen A. Antibiotic susceptibility of Staphylococcus aureus strains responsible for community-acquired skin infections. Ann Dermatol Venereol 2008;135(1):13-19. DOI: 10.1016/j.annder.2007.06.004.

9. Taira BR, Singer AJ, Thode HC, et al. National epidemiology of cutaneous abscesses: 1996 to 2005. Am J Emerg Med 2009;27(3):289292. DOI: 10.1016/j.ajem.2008.02.027.

10. Hartman-Adams H, Banvard C, Juckett G. Impetigo: diagnosis and treatment. Am Fam Physician 2014;90(4):229-235.

11. Wiese-Posselt $M$, Heuck D, Draeger A, et al. Successful termination of a furunculosis outbreak due to lukS-lukF-positive, methicillin- susceptible Staphylococcus aureus in a German village by stringent decolonization, 2002-2005. Clin Infect Dis Off Publ Infect Dis Soc Am 2007;44(11):e88-e95. DOI: 10.1086/517503.

12. Tinelli $M$, Monaco $M$, Vimercati $M$, et al. Methicillin-susceptible Staphylococcus aureus in skin and soft tissue infections, Northern Italy. Emerg Infect Dis 2009;15(2):250-257. DOI: 10.3201/eid1502.080010.

13. Golding GR, Levett PN, McDonald RR, et al. A comparison of risk factors associated with community-associated methicillin-resistant and -susceptible Staphylococcus aureus infections in remote communities. Epidemiol Infect 2010;138(5):730-737. DOI: 10.1017/ S0950268809991488.

14. Scheinfeld NS. Is blistering distal dactylitis a variant of bullous impetigo? Clin Exp Dermatol 2007;32(3):314-316. DOI: 10.1111/j.13652230.2007.02379.x.

15. Rush J, Dinulos JG. Childhood skin and soft tissue infections: new discoveries and guidelines regarding the management of bacterial soft tissue infections, molluscum contagiosum, and warts. Curr Opin Pediatr 2016;28(2):250-257. DOI: 10.1097/MOP.0000000000000334.

16. Mahmoodzadeh Hosseini $\mathrm{H}$, Kiyani $\mathrm{N}$, Amin M, et al. Distribution of high-level mupirocin resistance among clinical MRSA. J Chemother Florence Italy 2017;29(4):215-219.DOI: 10.1080/1120009X.2016.1201257.

17. Yu F, Liu Y, Lu C, et al. Dissemination of fusidic acid resistance among Staphylococcus aureus clinical isolates. BMC Microbiol 2015;15(1):210. DOI: 10.1186/s12866-015-0552-z.

18. Nagabushan H. Retapamulin: a novel topical antibiotic. Indian J Dermatol Venereol Leprol 2010;76(1):77-79. DOI: 10.4103/03786323.58693.

19. Hayden MK, Lolans K, Haffenreffer K, et al. Chlorhexidine and mupirocin susceptibility of methicillin-resistant Staphylococcus aureus isolates in the REDUCE-MRSA trial. J Clin Microbiol 2016;54(11):2735-2742. DOI: 10.1128/JCM.01444-16.

20. McNeil JC, Hulten KG, Kaplan SL, et al. Decreased susceptibilities to retapamulin, mupirocin, and chlorhexidine among Staphylococcus aureus isolates causing skin and soft tissue infections in otherwise healthy children. Antimicrob Agents Chemother 2014;58(5):28782883. DOI: 10.1128/AAC.02707-13.

21. Gropper S, Cepero AL, Santos B, et al. Systemic bioavailability and safety of twice-daily topical ozenoxacin $1 \%$ cream in adults and children with impetigo. Future Microbiol 2014;9(8 Suppl):S33-S40. DOI: $10.2217 / \mathrm{fmb} .14 .85$.

22. Chamny S, Miron D, Lumelsky N, et al. Topical minocycline foam for the treatment of impetigo in children: results of a randomized, double-blind, phase 2 study. J Drugs Dermatol JDD 2016;15(10):12381243.

23. Koning $S$, van der Sande $R$, Verhagen $A P$, et al. Interventions for impetigo. Cochrane Database Syst Rev 2012;1:CD003261. DOI: 10.1002/14651858.CD003261.pub3.

24. Ray GT, Suaya JA, Baxter R. Incidence, microbiology, and patient characteristics of skin and soft-tissue infections in a U.S. population: a retrospective population-based study. BMC Infect Dis 2013;13(1):252. DOI: 10.1186/1471-2334-13-252.

25. Liu C, Bayer A, Cosgrove SE, et al. Clinical practice guidelines by the infectious diseases society of America for the treatment of methicillin-resistant Staphylococcus aureus infections in adults and children: executive summary. Clin Infect Dis Off Publ Infect Dis Soc Am 2011;52(3):285-292. DOI: 10.1093/cid/cir034.

26. Bassetti $M$, Baguneid $M$, Bouza $E$, et al. European perspective and update on the management of complicated skin and soft tissue infections due to methicillin-resistant Staphylococcus aureus after more than 10 years of experience with linezolid. Clin Microbiol Infect Off Publ Eur Soc Clin Microbiol Infect Dis 2014;20(Suppl 4):3-18. DOI: 10.1111/1469-0691.12463.

27. Palit A, Inamadar AC. Current concepts in the management of bacterial skin infections in children. Indian J Dermatol Venereol Leprol 2010;76(5):476-488. DOI: 10.4103/0378-6323.69053.

28. Talan DA, Mower WR, Krishnadasan A, et al. Trimethoprimsulfamethoxazole versus placebo for uncomplicated skin abscess. N Engl J Med 2016;374(9):823-832. DOI: 10.1056/NEJMoa1507476. 
29. Holmes L, Ma C, Qiao H, et al. Trimethoprim-sulfamethoxazole therapy reduces failure and recurrence in methicillin-resistant Staphylococcus aureus skin abscesses after surgical drainage. J Pediatr 2016;169:128-134.e1. DOI: 10.1016/j.jpeds.2015.10.044.

30. Miller LG, Daum RS, Creech CB, et al. Clindamycin versus trimethoprimsulfamethoxazole for uncomplicated skin infections. N Engl J Med 2015;372(12):1093-1103. DOI: 10.1056/NEJMoa1403789.

31. Daum RS, Miller LG, Immergluck L, et al. A placebo-controlled trial of antibiotics for smaller skin abscesses. N Engl J Med 2017;376(26):25452555. DOI: 10.1056/NEJMoa1607033.

32. Gaspari RJ, Resop D, Mendoza M, et al. A randomized controlled trial of incision and drainage versus ultrasonographically guided needle aspiration for skin abscesses and the effect of methicillin-resistant Staphylococcus aureus. Ann Emerg Med 2011;57(5):483-491.e1. DOI: 10.1016/j.annemergmed.2010.11.021.

33. Singer AJ, Talan DA. Management of skin abscesses in the era of methicillin-resistant Staphylococcus aureus. N Engl J Med 2014;370(11):1039-1047. DOI: 10.1056/NEJMra1212788.

34. Singer AJ, Thode HC. Systemic antibiotics after incision and drainage of simple abscesses: a meta-analysis. Emerg Med J EMJ 2014;31(7):576-578. DOI: 10.1136/emermed-2013-202571.

35. Esposito S, Noviello S, Leone S. Epidemiology and microbiology of skin and soft tissue infections. Curr Opin Infect Dis 2016;29(2):109-115. DOI: $10.1097 /$ QCO.0000000000000239.

36. Montravers $P$, Snauwaert A, Welsch C. Current guidelines and recommendations for the management of skin and soft tissue infections. Curr Opin Infect Dis 2016;29(2):131-138. DOI: 10.1097/ QCO.0000000000000242.

37. Fahimi J, Singh A, Frazee BW. The role of adjunctive antibiotics in the treatment of skin and soft tissue abscesses: a systematic review and meta-analysis. CJEM 2015;17(4):420-432. DOI: 10.1017/cem.2014.52.

38. Yue J, Dong BR, Yang M, et al. Linezolid versus vancomycin for skin and soft tissue infections. Cochrane Database Syst Rev 2016(1):CD008056. DOI: 10.1002/14651858.CD008056.pub3.

39. Boucher HW, Wilcox M, Talbot GH, et al. Once-weekly dalbavancin versus daily conventional therapy for skin infection. N Engl J Med 2014;370(23):2169-2179. DOI: 10.1056/NEJMoa1310480.

40. Scott LJ. Dalbavancin: a review in acute bacterial skin and skin structure infections. Drugs 2015;75(11):1281-1291. DOI: 10.1007/ s40265-015-0430-x.

41. Moran GJ, Fang E, Corey GR, et al. Tedizolid for 6 days versus linezolid for 10 days for acute bacterial skin and skin-structure infections (ESTABLISH-2): a randomised, double-blind, phase 3, non-inferiority trial. Lancet Infect Dis 2014;14(8):696-705. DOI: 10.1016/S14733099(14)70737-6.

42. Prokocimer P, De Anda C, Fang E, et al. Tedizolid phosphate vs linezolid for treatment of acute bacterial skin and skin structure infections: the ESTABLISH-1 randomized trial. JAMA 2013;309(6):559-569. DOI: 10.1001/jama.2013.241.

43. Raff AB, Kroshinsky D. Cellulitis: a review. JAMA 2016;316(3):325-337. DOI: 10.1001/jama.2016.8825.

44. Williams DJ, Cooper WO, Kaltenbach LA, et al. Comparative effectiveness of antibiotic treatment strategies for pediatric skin and soft-tissue infections. Pediatrics 2011;128(3):e479-e487. DOI: 10.1542/ peds.2010-3681.

45. Dalal A, Eskin-Schwartz M, Mimouni D, et al. Interventions for the prevention of recurrent erysipelas and cellulitis. Cochrane Database Syst Rev 2017;20(6):CD009758. DOI: 10.1002/14651858.CD009758. pub2.

46. Ferreira A, Bolland MJ, Thomas MG. Meta-analysis of randomised trials comparing a penicillin or cephalosporin with a macrolide or lincosamide in the treatment of cellulitis or erysipelas. Infection 2016;44(5):607-615. DOI: 10.1007/s15010-016-0895-x.

47. Kilburn SA, Featherstone $P$, Higgins $B$, et al. Interventions for cellulitis and erysipelas. Cochrane Database Syst Rev 2010(6):CD004299. DOI: 10.1002/14651858.CD004299.pub2.

48. Montravers $P$, Bassetti $M$, Dupont $H$, et al. Efficacy of tigecycline for the treatment of complicated skin and soft-tissue infections in real-life clinical practice from five European observational studies. J Antimicrob Chemother 2013;68(Suppl 2):ii15-ii24. DOI: 10.1093/jac/ dkt141.

49. Chen LL, Fasolka B, Treacy C. Necrotizing fasciitis: a comprehensive review. Nursing (Lond) 2020;50(9):34-40. DOI: 10.1097/01. NURSE.0000694752.85118.62.

50. Stevens DL, Bryant AE, Goldstein EJ. Necrotizing soft tissue infections. Infect Dis Clin North Am 2021;35(1):135-155. DOI: 10.1016/j. idc.2020.10.004.

51. Bechar J, Sepehripour S, Hardwicke J, et al. Laboratory risk indicator for necrotising fasciitis (LRINEC) score for the assessment of early necrotising fasciitis: a systematic review of the literature. Ann R Coll Surg Engl 2017;99(5):341-346. DOI: 10.1308/rcsann.2017.0053.

52. Nawijn F, Smeeing DPJ, Houwert RM, et al. Time is of the essence when treating necrotizing soft tissue infections: a systematic review and meta-analysis. World J Emerg Surg WJES 2020;15(1):4. DOI: 10.1186/ s13017-019-0286-6.

53. Burnham JP, Kollef MH. Treatment of severe skin and soft tissue infections: a review. Curr Opin Infect Dis 2018;31(2):113-119. DOI: 10.1097/QCO.0000000000000431.

54. Bonne SL, Kadri SS. Evaluation and management of necrotizing soft tissue infections. Infect Dis Clin North Am 2017;31(3):497-511. DOI: 10.1016/j.idc.2017.05.011.

55. Gadepalli R, Dhawan B, Kapil A, et al. Clinical and molecular characteristics of nosocomial meticillin-resistant Staphylococcus aureus skin and soft tissue isolates from three Indian hospitals. J Hosp Infect 2009;73(3):253-263. DOI: 10.1016/j.jhin.2009.07.021.

56. Perumal N, Dass BS, Mani S, et al. Prevalence of bi-component poreforming toxin genotypes of Staphylococcus aureus causing skin and soft tissue infections. Indian J Med Microbiol 2017;35(1):146-147. DOI: 10.4103/ijmm.IJMM_16_424.

57. Phakade RS, Nataraj G, Kuyare SS, et al. Is methicillin-resistant Staphylococcus aureus involved in community acquired skin and soft tissue infections? Experience from a tertiary care centre in Mumbai. J Postgrad Med 2012;58(1):3-7. DOI: 10.4103/0022-3859.93245.

58. Zwemer E, Stephens JR. Things we do for no reason: blood cultures for uncomplicated skin and soft tissue infections in children. J Hosp Med 2018;13(7):496-499. DOI: 10.12788/jhm.2984. 